\title{
German Communication Studies facing the challenge of digital media change: debates and controversies in the scientific community since the 1990 s
}

\author{
Estudos Alemães de Comunicação enfrentam o desafio da mudança da mídia \\ digital: debates e controvérsias na comunidade científica desde a década de \\ 1990
}

\author{
Erik Koenen \\ University of Bremen \\ <ekoenen@uni-bremen.de> \\ Christina Sanko \\ University of Bremen \\ <sanko@uni-bremen.de>
}

\section{ABSTRACT}

The article deals with the development of German Communication Studies since the mid-1990s until today. Its focus lays on the discussions on new media and their consequences for the redefinition of the scientific field as "New Communication Science". Different to the scientific tradition of the 'old' German "Publizistikwissen-schaft" with the main focus on mass media and public communication, the 'new' field is characterized by a broader view on communication and media in reaction to the interweaving of interpersonal and media communication in the digital age. Ac-cording to the idea of science as social process, this paper asks how the new orien-tation gained acceptance in the scientific community and reconstructs the scholarly debates on this path. These include external triggers of debate such as the Silbermann controversy that resulted in the appointment of an internal self-conception committee and the very first paper on the profile of the discipline in Germany. The reconstructed debates in this paper outline the development of two strands within the scientific community: traditionalists and visionaries. Although the intensity of discussions on the disciplinary identity of German Communication Studies abated since the adoption of the second self-conception paper that embraced the diversity of the discipline, debates on the extension versus limitation of the range of research subjects in the course of changing media environments and societies prevail until present day.

Keywords: Germany. New Media. New Communication Studies.

\section{RESUMO}

O artigo aborda o desenvolvimento dos estudos alemães de comunicação, da meta-de dos anos 1990 à atualidade. Seu foco reside nas discussões sobre a nova mídia e seus efeitos no tocante à redefinição deste campo científico como "nova ciência da comunicação". Diversamente da tradição científica alemã conhecida como "Pu-blizistikwissenschaft", focada, sobretudo nos meios de massa e na comunicação pública, o "novo" campo se caracteriza por ter uma visão mais ampla da comunica-ção e seus meios, reagindo ao entrelaçamento entre comunicação interpessoal e midiática em curso na era digital. Sintonizado com a ideia de ciência como processo social, o artigo pergunta sobre como a nova orientação conquistou aceitação na comunidade científica alemã e reconstrói os debates acadêmicos que a acompa-nharam. Entre estes últimos, incluem-se os que tiveram disparo externo, como a controvérsia em torno de Silbermann, que resultou na indicação de comitê conceitual interno e na redação do primeiro perfil da disciplina interno à área na Alema-nha. A reconstrução dos debates feita no artigo revela o desenvolvimento de duas correntes na sua comunidade científica: os tradicionalistas e os visionários. Apesar da intensidade das discussões a respeito da identidade disciplinar dos estudos de comunicação alemães ter diminuído após a adoção de um segundo perfil, que lo-grou abranger a diversidade da disciplina, ainda hoje vigoram debates sobre a extensão e limites de seus temas de pesquisa em meio a um cenário social e midiático sujeito a mudanças. 
Adding to the series on history of communication studies and traditions of the discipline in Germany (Averbeck-Lietz, 2014; Koenen and Sanko, 2016) the article examines recent developments of the discipline during the last two decades. Challenged by the emergence of new media in the digital age, communication studies in Germany is tremendously changing since the 1990s: from traditional communication studies holding on to its origins in German "Publizistikwissenschaft" and focusing its interest particularly on the subject of mass or publicly mediated communication and the conditions, forms and functions, the organization and structures as well as the consequences and effects of public communication processes to "new communication studies" (Löffelholz and Quandt, 2003). Martin Löffelholz and Thorsten Quandt, who marked this process of change first, stated:

At the beginning of the 21st century, communication studies will face many new questions. The general determination of the research subject did not change however: It is still about the description and analysis of communication processes. Beneath this general level there is a lot of movement of course. [...] What is clear: In the internet age the research subject of communication studies is changing radically. The classic distinction of interpersonal and mass-mediated communication gives way to a hybrid-media communication system (Löffelholz and Quandt, 2003, p. 25-26). ${ }^{1}$

Systematically, the reorientation to "new" communication studies is particularly characterized by constant expansion, differentiation and redefintions of the range of research subjects and topics as well as respective methodological and theoretical adjustments.This way communication studies faces disciplinary challenges and needs to academically cope with vast societal and media changes that were stimulated by drastic, complex and consequential media technical innovation processes such as computerization, digitization and multimedialization since the 1990s. As any other looming paradigm shift, these developments did not occur without discrepancy as a plea by Hans-Bernd Brosius (2003) shows. In his view back then, debates on "new" communication studies, including media of the digital age, were "excitements due to fascinations with technology".This article therefore concentrates on the still on-going debates on "new" communication studies and reconstructs these as discussion process within the discipline. Changing external influences such

1 All German quotations are translated by the authors. 
as new media environments can at best trigger the reconsideration of scientific and epistemological interests, subjects and objectives. If these lead to thematic reorientations or even a paradigm shift in the sense of Thomas S. Kuhns (1976), these need to be discussed, negotiated and argued upon by scientists. Particularly "the decision for a new paradigm is also always a social process that is about convincing others" (Felt, Nowotny and Taschwer, 1995, p. 126).

\section{The Silbermann controversy 1996-97: Beginning of a new debate}

Among various political and programmatic pleas about the state and the future of German Communication Studies since the 1980s (Saxer, 1980; Baum; Hachmeister, 1982; Rühl, 1985; Glotz, 1990; Wagner, 1993) none had an impact as great as the polemic by cultural sociologist Alphons Silbermann that was published in the German weekly Die ZEIT at the end of 1996. Silbermann, the enfant terrible and "contradictory and stubborn all-rounder", placed a snarky "swan song about German media and communication studies" in the renowned weekly(Rühl, 1997, p. 158). He accused the discipline of "unrealistic uselessness" and "quirky bumbledom" in regard to a massively changing media environment in the course of digitization, computerization and multimedialization. He further blamed representatives of the discipline of a "fatal tendency to self-affirmation" with the consequence "that many of the university representatives of the discipline have veered away from social reality, so they do not becomeaware of the dangers to their scientific branch, which is being only rarely if not all in demand" (Silbermann, 1996). Members of the discipline obviously felt highly provoked by this outsider. "Silbermann does not know the communication and media studies of the past 20 years, particularly not internally", responded for example Günter Bentele (1997), then head of the Deutsche Gesellschaft für Publizistikund Kommunikationswissenschaft (German Communication Association).

If you read Silbermann's polemic and the following reactions again from today's point of view, it leaves most notably the impression that Silbermann exposed an absolutely essential need of reflecting upon the identity of German Communication Studies despite the criticized ignorance about the state of the discipline in the mid-1990s. In a way, the provocation had been "overdue", Stephan Ruß-Mohl (1997) said in his objection. Also other pleas admitted issues and together assembled "different perspectives of the 'state-of-the-art' of the discipline" (Rühl, 1997, p. 162). These, if systematized in a "situational analysis of the discipline's politics" (Löblich, 2010, p. 107) indicate that the discipline's problem of "expansion vs. concentration" as it has been already observed in the 1980s not only persisted, but was about to consolidate into diametrical perspectives of the discipline (Koenen and Sanko, 2016). 
This is illustrated by various different evaluations of the discipline's concept and its treatment of new media at the advent of the digital age. While Irene Neverla referred to the discipline as as consolidated and professional one. While she stated that "the struggle for identity formation on the one hand and for interdisciplinarity on the other hand" is "simply not an issue anymore" (Neverla, 1997), Günter Bentele and Stephan Ruß-Mohl considered the interdisciplinarity and openness of communication studies as major problems."Particularly because it, different from economics for example, does not have its own methodological 'approach', centrifugal forces unfold", Ruß-Mohl (1997) stated and added:"Different lines of thought and theories of neighboring disciplines have always influenced the discipline. These different ways of thinking can hardly be integrated in one 'discipline' and are difficult to overview due to their plurarlity". "The additive coexistence of various approaches in fact supports the understanding of communication and media studies as inclusive discipline, but it lacks a standardized transfer of knowledge, the number of good textbooks is limited", Bentele (1997) criticized.

Besides the eclectic coexistence of various concepts and theories from different disciplinary contexts, Bentele (1997) further critically discussed the "permanent expansion" of the range of research subjects and objects that has constantly accompanied the discipline since its foundation as newspaper science and was stimulated by media change: "First the newspaper was the only research object, then the magazine, later radio broadcasting, film and television, the 'new media' of the 1980s (BTX, cable and satellite television etc.) were included. Today many starr at 'multimedia' ". Similar to representatives of the discipline 15 years ago such as Franz Ronneberger, who had advocated a stronger limitation, focus and concentration and had warned about the "explosion of communication studies" (Kröll, 1980, p. 507; Koenen and Sanko, 2016), Bentele (1997) therefore criticized that "regarding a constant big number of students, the resources of the discipline are way too low to handle all this". For this reason, the formal focus on public communication as a "clearly defined research subject" seemed to be sufficient for him to justify social and academic relevance.

This limited focus on public communication did not remain uncontested within the German scientific community as illustrated by the number of responses to Silbermann published in the German Communication Association's own publication Aviso: for about four years discussions and arguments about the subject and sense of the discipline went on. Hans-Jürgen Bucher and Hans-Dieter Kübler (1997) for example wondered, whether the scope of communication studies "had not expanded", but "rather narrowed" during the last decades. They argued that "the guild shall look beyond its own nose" (Bucher and Kübler, 1997, 
p. 6), taking again a stronger interdisciplinary approach in methods and theories. That includes to increase again the "qualitative, hermeneutic and critical parts of media research" that were marginalized in the course of the empirical socioscientific turn:

\begin{abstract}
As important as quantitative research findings are for questions about the reception of media contents, for questions about the quality of its creation, for an explanation of media contents that takes into account communication dynamics and its production history, for the analysis of media historical changes of forms of representation and presentation as well as for conceptual thoughts on media development quantitative data must be supplemented by qualitative (old-fashioned: humanities-based) research strategies (Bucher and Kübler, 1997, p. 7).
\end{abstract}

Considering new media environments of the digital age, they added to their critique that the focus on public communication within the discipline does not correspond adequately to the rapidly changing research field: "Public communication' is not a clearly defined research subject and it is becoming even less the more media technological development and the entanglement of closed and open circles of users (publics) proceed" (Bucher and Kübler, 1997, p. 7). This is, however, not only because the research subject changes, but also because the knowledge competition for these media developments on the side of other disciplines is growing. That is why this question needs to be reconsidered if one does not want to be "lapped" "by modern disciplines that already react to or even push this development such as informatics and information science, cognitive science, computer science, systems and network management, software engineering, media design, teleteaching et cetera" (Bucher and Kübler, 1997, p. 7). As a result of the traditional focus on public communication, Gernot Wersig (1997) considered communication studies poorly prepared to tackle these "new challenges" of "digitization, multimedia, internet, virtual realities, and the like" methodologically and theoretically:

It could decently cope with the traditional media system, for which theoretical stocks from former weddings were sufficient. With new technologies and forms of organization that are hardly bound to one medium, previous concepts such as 'media' or 'public' increasingly loose their orienting function; the human being as an intersection of 
Peter Szyszka (1998) also regarded the concentration on "mass communication science that sets its focus on journalistic mass media and public opinion"as"counterproductive", because it loses sight of "a generalunderstanding of social communication" (Szyska, 1998, p. 9). Finally, Hans Bohrmann (1999) warned insistently about an overexpansion of media as research subjects. Instead one should rather concentrate on the parts one methodologically and thematically knows about. In this way, "media communication" defines - "no ifs and buts" the common anchor of communication studies even in the new media situation of "the now emerging network communication" (Bohrmann, 1999, p. 6).

Traditionalists and visionaries - these are the two strands that have evolved within the scientific community of German Communication Studies as a reaction to the controversy on the establishment and selfreflection of the discipline initiated by Silbermann. The visionaries stated a lacking disciplinary openness towards the considered rapid media change and claimed to open up the discipline. They demanded a substantial reconsideration of how its formal perspective on knowledge and research subjects as well as methodological and theoretical tools can be newly defined and expanded particularly regarding the beginning age of digital media. Traditionalists such as Hans-Bernd Brosius (2003) realized on the other hand that a "relatively broad, if not too broad understanding of the research subject" is rather dangerous for the discipline, because "identifiability" and exclusive "core competences" get lost: Despite or just because of all the "technological euphoria" the discipline of communication studies would need "a clear focus on its research subject and this is public communication" (Brosius, 2003, p. 47- 48).

"The Media Society and its Science": The first declaration on the selfconception of German Communication Studies

As one outcome of the Silbermann-controversy, the German Communication Association, the professional association of the discipline, appointed a self-conception committee (Selbstverständnisausschuss) in October 1998 (Rössler and Theis-Berglmair, 1999; Theis-Berglmair, 1999, 2000) in order to clarify the question on the "internal identification of the discipline and its external representation" (Theis-Berglmair and Kohring, 2000, p. 29) for the scientific community. The result was a document with the programmatic title The Media Society and its Science (Die Mediengesellschaft und ihre Wissenschaft; DGPuK 2001) primarily prepared by Günter Bentele and Hans-Bernd Brosius 
(Bentele 1999; Brosius 1999) and passed by the self-conception committee in 2001. The paper encouraged particularly the branded core of the discipline since the empirical socio-scientific turn of the 1960s and 1970s (Koenen and Sanko, 2016), namely mass and public communication, and defined its place within the disciplinary context of social science as internal consensus: "German Communication Studies in its core understands itself today as a theoretical and empirically working social science with interdisciplinary references" (DGPuK, 2001, p. 7).

Despite the ascertainment that growing media penetration in modern societies as the main scientific challenge is carried, stimulated and advanced not only by "traditional, publicly oriented communication media such as the press, television, radio or film" but primarily by "new electronic forms of communication that enable computer networks and their audiovisual means of communication" (DGPuK, 2001, p. 1), it is stated in the paper that "in the center of the discipline" "stands indirect, public communication mediated through mass media" (DGPuK, 2001, p. 3). Although telecommunication media such as the telephone, "various forms of computer-mediated communication (e.g. World Wide Web, internet, intranet)" and not least the communicative "basic phenomenon" of "interpersonal communication" would also belong to the research field of communication studies, they are only interesting for the discipline as long as their are explicitly "connected to public communication processes" (DGPuK, 2001, p. 3).

Contrary to the accelerating media change, the declaration overall represented a plea for keeping epistemological and thematic continuity. According to Hans-Bernd Brosius (2003), the discipline shall concentrate on the solid "core operations, the further development of theories and methods of the science of public communication" that have been predominant since the empirical socio-scientific turn instead of "instinctively" succumbing to the "fascination with the new": "The phenomena, the appearance of media are changing; the processes behind it are not. And that is why, from my point of view, there is no new communication studies even in the age of the meta- or hybrid medium internet"(Brosius, 2003, p. 45-47). In the argument about subject, contents and direction of German Communication Studies, the traditionalists therefore asserted themselves, which was surely connected to the fact that the claims by the visionaries of an expansion and new orientation of the perspective of the discipline essentially were programmatic and hardly found support within "the realities of research" as Ralf Hohlfeld and Christoph Neuberger (1998) pointed out in their study on the development of a thematic research profile in 
German communication journals: "Public, indirect communication with a mass public, namely 'mass communication', stayed dominant almost throughout the whole sampling period. [...] Overall, the thematic expansion of the discipline from the center to the peripheries remained low" (Hohlfeld and Neuberger, 1998, p. 331-332).

\section{"Threatening desintegration" and "increasing complexity": German Communication Studies in confusion}

Even though, it can be assumed that the research area of public communication and the positioning of German Communication Studies as "theoretically and empirically working social science" (DGPuK, 2001, p. 7) was widely established within the scientific community and represents a common consensus in applied research, the question on profile and perspective of the discipline was certainly not off the table with the publication of the first selfconception paper in 2001. On the contrary: it remained virulent and shortly became topic number one in the internal debates of the discipline again.

Already in 2005, a working group on the discipline's future (Arbeitsgruppe Fachperspektive) put the topic on self-conception back on the daily political agenda - with the outcome that one year later the German Communication Association established a self-conception committee again. Asking for the reasons for the short half-life of the passed draft of 2001, there are three particular answers. First, the limitation on public communication largely ignored the issue of expansion and diversification of the range of research and topics within the discipline in the age of the meanwhile advanced stage of the digital revolution, which at the same time drastically limited its relevance for and application to present phenomena. Secondly, the preferred empirical and socioscientific orientation marginalized not only representatives of humanitiesoriented leanings of the discipline that are equally rich in tradition, but also missed the social reality of an increasingly pluralistic and heterogeneous scientific community of German Communication Studies. Instead of disciplinary limitation and homogeneity the previously mentioned working group favored interdisciplinarity, openness and plurality as written in their position paper. That way, it tried"toselectintegrativeformulationsand tonameoptionsforcooperation and links to other disciplines" (Selbstverständnisausschuss der DGPuK, protocol of the session on October 20th, 2006, p. 10, statement Andreas Hepp):

Since its beginnings communication and media studies has understood itself as science of integration that picks up theories and methods of various social sciences and the humanities and 
brings them into its perspective. This is a great strength regarding contemporary'knowledge and media societies', in which relevant sets of knowledge cannot be divided into the 'boxes' of university subjects (anymore): Communication and media studies is therefore highly adaptable for other disciplines (Arbeitsgruppe Fachperspektive, 2005)( DGPuk, 2006, p.10).

Finally, there was a third reason for "protests", namely the procedure of the identification process itself. The scientific community remained largely uninvolved, which provoked criticism that the process was "not participatory enough" (Selbstverständnisausschuss der DGPuK, protocol of the session on October 20th, 2006, p. 11, statement Gabriele Siegert). Guido Zurstiege (2006) stated regarding the validity of the self-conception paper:

I would like to put emphasis on the fact, however, that this paper was collectively elaborated by two members of the scientific community and it was published for many, indeed: over 700 members of this scientific community. It is meant to be the least common denominator of an expanding discipline, and therefore, you will hardly find any institute in Germany, any approach or school, that can fully subscribe to it (Zurstiege, 2006, p. 86).

Under these conditions the self-conception paper primarily corresponded to the political aim to define the discipline externally, to delineate itself and thus contribute to "the transparency of the discipline for others" (Theis-Berglmair, 2000, p. 8). The paper hardly managed to serve the secondary aim. That was to formulate a consensus internally to generate a disciplinary identity within the scientific community - a consensus that would pick up the "manifold, sometimes even contradictory perspectives" (Rössler and Theis-Berglmair, 1999, p. 7) within the discipline and integrates them. The situation back then showed that the official self-conception of disciplinary heterogeneity of the scientific community and its connected "multiple scientific orientations" and "increasing complexity" (Wirth, 2000, p. 38) did not do justice within the discipline. In their survey with members of the German Communication Association on the state and the identity of the discipline and its community Wolfram Peiser, Matthias Hastall and Wolfgang Donsbach (2003, p. 333) found a striking coexistence of scientific perspectives. The majority of respondents share the categorization of the discipline as social science and the corresponding empirical socio-scientific profile as presented in the paper. The study concluded that the discipline "had 
gained contours and had developed something like a mainstream" (Peiser, Hastall and Donsbach, 2003, p. 332). Yet, respondents called for an equal acknowledgement and representation of socio-scientific and humanitiesoriented perspectives. In this view, the strong focus of the discipline's identity on the socio-scientific mainstream seems even more dysfunctional for the social integration of the discipline, "because the actual or the alleged minorities [...] feel less in good hands - within the discipline as well as the scientific community" (Peiser, Hastall and Donsbach, 2003, p. 333):

Representatives of scientific orientations that are less prominently represented in the German Communication Association, perceive the discipline's association as one-sided and anonymous; they share the 'official' self-conception less, apparently feel not that integrated and see their interests less well represented by the association(Peiser, Hastall and Donsbach, 2003, p. 332).

Regarding the force of integration, which the self-conception can still unfold in this situation, Jürgen Wilke (2005/2006, p. 336) stated sceptically: "It is certainly important that an imminent desintegration of the 'integrative' discipline of German Communication Studies is countervailed with such a position paper." Many "new issues" would "force the discipline to new considerations about what its core subjects and disciplinary criteria are" (Wilke, 2005/2006, p. 336-337).

\section{Necessary reorientations}

With the Bologna process, the growing competition between disciplines by media studies and new scientific and political ideals such as elite research and competition for excellence there were - beside the internal and unsolved identity issue - "many good reasons" (Selbstverständnisausschuss der DGPuK, protocol of the session on October 20th, 2006, p. 3, statement Gerhard Vowe) externally for a repetition of the discussion on contents, core and perspective of German Communication Studies. Enough reasons for the German Communication Association to initiate another self-conception committee that started its work in autumn 2007 (Stöber, 2006). Other than in the previous discussion, the debate now was much broader and tried to include as much voices, orientations and schools of thought as possible in the self-conception process. The wide range of issues that needed to be negotiated for a amended version of the self-conception was described by Otfried Jarren in the first session as follows: 
The important aim is the search for commonalities and divisions within the discipline and in distinction to other disciplines. In education and training, homogenization should be one objective; it needs to be more structured. In research, the principle of diversity applies anyway. Moreover, the discussion about the state of the higher education system in times of marketization and liberalization as well as the improving positions of universities of applied science and private academies is important(Selbstverständnisausschuss der DGPuK, protocol of the session on October 20th, 2006, p. 3, statement Otfried Jarren).

The rapidly on-going "change of media, communication and society" as research subject of the discipline, the corresponding "rapid change of the research environment", its "differentiation", "internationalization" and "expansion" were further urgent points of debate for the members of the committee within this restarted process of self-reflection (Selbstverständnisausschuss der DGPuK, protocol of the session on October 20th, 2006).

In his final report for Aviso, Rudolf Stöber (2006, p. 27) stated that overall "issues, which are far from trivial, have accumulated". Neither the definition of a range of research subjects of current, mass-mediated and public communication nor the ones of methodology and the perspective of an empirical and socio-scientific-oriented discipline are sufficient to form an identity-sustaining consensus. Both run risk of "unilateral determination", "limitation" and "paternalism" on the one hand, and the overexpansion of the responsibilities of the discipline for - in a broad sense - all social phenomena linked to communication and media on the other hand (Stöber, 2006, p. 27).

At the same time, the German Council of Science and Humanities (Wissenschaftsrat) ${ }^{2}$ dealt with the reorganization of the field "communication and media". Particularly, this circumstance and the current state of the discipline urged the pragmatic and goal-oriented development of an exclusive profile that would take into account new challenges and overcome inner tensions. Therefore, one could not afford a fundamentalization of the debate or lengthy discussions. In 2007, the German Council of Science and Humanities published Recommendations for the Development of Communication and Media Studies in Germany (Empfehlungen zur Weiterentwicklung der Kommunikations- und Medienwissenschaften in Deutschland). It stated that one "deals with a very heterogeneous, extremely dynamic and for that reason partly confusing scientific field", within which "varied research approaches, study programs

2 "The Council of Science and Humanities (Wissenschaftsrat, WR) is one of the leading science policy 
and new disciplines or scientific fields with proto-disciplinary status" evolve and differentiate themselves (Wissenschaftsrat, 2007, p. 11-13). Referring directly to German Communication Studies, the council evaluated that the discipline institutionally "successfully constituted" itself through its exclusive epistemological focus on mass-mediated, public communication (Wissenschaftsrat, 2007, p. 74). However, regarding "the profound and rapid changes of modern media culture, which can be marked by keywords such as digitization, connectivity, acceleration or globalization" (Wissenschaftsrat, 2007 , p. 73), the discipline is confronted with the immediate challenge to set a new disciplinary perspective and thus to position itself again within a larger disciplinary field of "communication and media studies" - the central question therefore should be to what extent the discipline is able to "appropriately observe and reflect the socio-cultural changes that go along with with media dynamics" (Wissenschaftsrat, 2007, p. 14). In this regard, the council advised that German Communication Studies in the future needs to include more "the entanglement of public and non-public communication processes" as well as "the dynamics and flexibilization of communication processes and situations triggered by technological developments" besides the traditional subject of "mass media and public communication" (Wissenschaftsrat, 2007, p. 19f.). Instead of solely relying on the socioscientific theoretical imports, exclusive basic research of communication studies needs to be pushed in order to sustain the epistemological competence and relevance within these developments in the longrun:

\footnotetext{
The challenges communication studies is already facing now call for a strengthening of general theory-building in communication and media studies. The import of theories from the neighboring social sciences alone is not sufficient to appropriately grasp the dynamic change of modern media culture in terms of terminology, methodology and theory that results from technological revolutions and societal changes (Wissenschaftsrat, 2007, p. 75).
}

advisory bodies in Germany. It advises the Federal Government and the governments of the German Länder (Federal States). It produces recommendations on the development of science, research and higher education, thus helping to ensure that German science and humanities remain competitive at national, European and international level. The recommendations of the Wissenschaftsrat involve considerations concerning quantitative and financial effects and the implementation of such considerations, always taking into account the demands of societal, cultural and economic life." Available in: < $\underline{\text { https:// }}$ www.wissenschaftsrat.de/en/about/function.html>. Access in: 31 mar. 2017. 
Representing the self-conception committee, its head Gerhard Vowe (2007, p. 5-6) welcomed the "political impetus" of the German Council of Science and Humanities and the resulting tailwind for the self-reflection of the discipline: "The German Council of Science and Humanities explicates that a little more order would be good and that this needs to be communicated clearly". Many of the recommendations in their essence (more internationalization, greater integration of the diverse traditions and perspectives of the discipline, more interdisciplinary cooperation and in this sense particular openness towards media studies) would actually correspond with the internal identification process and support a "solid basement for a renewed self-conception" (Vowe, 2007, p. 6).

\section{"Communication and Media within Society": a new self-conception for German communication and media studies}

The newand today still valid self-conception paperentitled Communication and Media within Society (DGPuK, 2008) was presented to members of the German Communication Association in Lugano in 2008. As a result of the discussions outlined above the document does not aim to grasp the discipline of German Communication Studies deductively through exclusive categories such as mass media, public communication and socioscientific orientation anymore. Instead it rather contours an original research subject through a set of guiding research questions and problems, to which the discipline can contribute exclusive "work for the enlightenment of society by basic research" and thus justifies its relevance (DGPuK, 2008, p. 4). As a central effort knowledge on the "interplay of communication, media and society" is put into "focus" and and is specified by three guiding questions: "What is the meaning of communication and media for society? Under which societal and media conditions does communication develop? How do societal and communicative conditions affect the media?" (DGPuK, 2008, p. 4). With this rather broad focus on "history, present and future" of "social conditions, consequences and meanings" of communication and media the range of research subjects is clearly extended (DGPuK, 2008, p. 1). Against the backdrop of media and societal change"other forms of communication and their entanglement" become increasingly important from a communications point of view, looking beyond "traditional (mass-)mediated public communication": "Mediated, public and interpersonal communication" are even referred to as "equal" research subjects (DGPuK, 2008, p. 1-3). Beyond this offensive openingup of the formal perspective of the discipline that accomodated the issue of the ongoing diversification of the range of research subjects in communication studies, various traditions and origins of the discipline within the humanities 
and social sciences as well as the resulting variety of methods and theories are integrated: There "is no dominating theory", communication studies is rather "marked by a plurality of theories, methodologies and concepts". That is why in applied research "methods of empirical social science and historicalhermeneutic methods" as well as "standardized and non-standardized methods" coexist (DGPuK, 2008, p. 3).

With the extension of the range of research subjects to diverse forms of mediated or media-related, interpersonal, public and non-publiccommunication and the corresponding pluralization of methodological and theoretical perspectives that encompass an inclusive discipline of "communication and media studies", the self-conception paper set a clear signal towards a thematic and social identity. On the one hand, it generates a basic cosensus and provides clear orientation regarding the question what the discipline is for and what it is supposed to do. On the other hand, it is sufficiently open in order to integrate the whole diversity of the scientific community, specific teaching and research profiles as well as theoretical backgrounds and positions. That the new position paper with the basic points of opening-up and broadening of the disciplinary perspective and the range of subjects, integration of the diversity of perspectives as well as methodological and theoretical pluralism was a good and solid consensus to guarantee identity and profile at the same time is shown not least by the great approval, when the paper was passed.

\section{Conclusion}

The observation that discussions on the disciplinary identity of German Communication Studies have ceased within the scientific community since the self-conception paper took effect in 2008 shows its high power of inner, social integration and great thematic flexibility to contour a perspective that tackles permanent challenges of a still highly dynamic, multi-dimensional and complex structural change of society, communication and media. Against this backdrop the range of subjects and the efforts of the discipline expected by society is constantly expanding and changing. According to the findings of the study Research Environment Communication and Media Studies (Forschungslandschaft Kommunikations- und Medienwissenschaft) initiated by the steering committee of the German Communication Association in 2009, a "remarkable diversity" has developed under the self-conception umbrella: "Beyond a clearly outlined core the discipline is further diversifying itself. Although communication studies as inclusive social science constantly faces new strands, which further vary thematic, theoretical and methodological research activities" (Altmeppen, Franzetti and Kössler, 2013, p. 50, 51). Particularly, the long problematized 
double-challenge of the discipline to always develop new subjects and topics, to integrate them and to strengthen and profile its core is managed better and better. Therefore an "overall development towards a unity of the discipline can be declared" (Altmeppen, Weigel and Gebhard, 2011, p. 394), which corresponds to the intended reorientation of the self-conception towards new, thematically and socially open and plural communication studies.

That does not mean, however, that there are no more discussions within the German scientific community about the research subject and perspective of communication studies. Only recently, Andreas Hepp (2016, p. 240) appealed to the community that in regard to the eminent mediatization of society and lifeworlds that is currently pushed by datafication and digitization, the following question needs to be taken care of: "how does communication and media studies need to develop in order to provide an appropriate approach to today's deep mediatization". The following debate continued in a specific panel on the topic at the German Communication Association's latest annual conference in March 20173. Andreas Hepp called for the extension of the range of research subjects to data and a corresponding fundamental reconsideration of existing theories. Although Hans-Bernd Brosius acknowledged the relevance of "bots and algorythms" and agreed on a possible adjustment of prevailing theoretical strands "without jettisoning them", he yet raised concerns about the limitations of available methodological instruments within the discipline to adequately deal with data. While Anna Maria Theis-Berglmair pointed out parallels to earlier disciplinary self-conception debates since the 1990s, compared to earlier controversies about the foundations and the core of the discipline's identity and despite diverging standpoints (Brosius 2016; Jarren 2016; Theis-Berglmair 2016), the recent discussion is much more calm and its argumentations a much more self-evident component within the self-conception process within the scientific community of communication and media studies in Germany.

\section{REFERENCES}

ALTMEPPEN, Klaus-Dieter; WEIGEL, Janika; GEBHARD, Franziska. Forschungslandschaft Kommunikations- und Medienwissenschaft. Ergebnisse der ersten Befragung zu den Forschungsleistungen des Fachs. In: Publizistik, v. 56, n. 4, p. 373 - 398, 2011.

ALTMEPPEN, Klaus-Dieter; FRANZETTI, Annika; KÖSSLER, Tanja. Das Fach Kommunikationswissenschaft. Vorschlag einer Systematisierung auf empirischer Grundlage. In: Publizistik, v. 58, n. 1, p. 45 - 68, 2013.

3 The following remarks are based on personal observations by the authors during the conference. 
ARBEITSGRUPPE FACHPERSPEKTIVE (working group on the discipline's future). Die Deutsche Gesellschaft für Publizistik- und Kommunikationswissenschaft auf dem Weg zur Fachgesellschaft für Kommunikations- und Medienwissenschaft, 2005. Available: http://www.dgpuk.de/meine-dgpuk/ aus-dem-verein/dokumentationen/ Accessed in: 31 mar. 2017.

AVERBECK-LIETZ, Stefanie. Da ciência do periódico à "ciência da liderança nacionalsocialista": como os estudos de imprensa adotaram o regime nazista na Alemanha. In: Revista FAMECOS, v. 21, n. 2, mai/ago., p. 418 - 437, 2014.

BAUM, Achim; HACHMEISTER, Lutz. Zur Soziologie der Kommunikationswissenschaft. In: Rundfunk und Fernsehen, v. 30, n. 2, p. 204 - 215, 1982.

BENTELE, Günter. Das Fach ist höchst attraktiv. Die Absolventen haben große Berufschancen. Eine Replik auf Alphons Silbermann. In: Die Zeit, n. 6, 1997. Available: http://www.zeit.de/1997/06/bentele.txt.19970131.xml Accessed in: 31 mar. 2017.

. Gegenstands- und Problembereiche, Systematiken, Theorien und Methoden unseres Fachs. In: Aviso, n. 24, p. 4 - 8, 1999.

BOHRMANN, Hans. Im Zentrum steht Medienkommunikation. In: Aviso, n. 23, p. 6, 1999.

BROSIUS, Hans-Bernd.. Acht Thesen zur wissenschaftspolitischen Positionierung des Fachs. In: Aviso, n. 24, p. 5, 1999.

Aufgeregtheiten durch Technikfaszination. Trotzdem und gerade deshalb: Die neue ist die alte Kommunikationswissenschaft. In: LÖFFELHOLZ, Martin; QUANDT, Thorsten (eds.). Die neue Kommunikationswissenschaft. Theorien, Themen und Berufsfelder im Internet-Zeitalter. Eine Einführung. Wiesbaden: Westdeutscher Verlag, p. 43 - 48, 2003.

. Warum Kommunikation im Internet öffentlich ist. Zu Andreas Hepps Beitrag "Kommunikations - und Medienwissenschaft in datengetriebenen Zeiten". In: Publizistik, v. 61, n. 4, p. 363 - 372, 2016.

BUCHER, Hans-Jürgen; KÜBLER, Hans-Dieter. Aufbruch zur Interdisziplinarität: Frischen Wind in die Stube bringen. Kommunikations- oder Medien- oder...was? In: Aviso, n. 19, p. 6 - 7, 1997.

DEUTSCHE GESELLSCHAFT FÜR PUBLIZISTIK- UND KOMMUNIKATIONSWISSENSCHAFT (DGPuK; = German Communication Association). Die Mediengesellschaft und ihre Wissenschaft. Herausforderungen für die Kommunikations- und Medienwissenschaft als akademische Disziplin. Selbstverständnispapier, erarbeitet vom Selbstverständnisausschuss unter der Leitung von Anna M. TheisBerglmair und Günter Bentele in Zusammenarbeit mit dem Vorstand der DGPuK Hans-Bernd Brosius, Romy Fröhlich und Helmut Scherer. München, 2001. 
Kommunikation und Medien in der Gesellschaft. Leistungen und Perspektiven der Kommunikations- und Medienwissenschaft. Eckpunkte für das Selbstverständnis der Kommunikations- und Medienwissenschaft. Selbstverständnispapier der DGPuK, 2008. Available in: www.dgpuk.de/wpcontent/uploads/2012/01/DGPuK_Selbstverstaendnispapier-1.pdf Access in: 31 mar. 2017.

FELT, Ulrike; NOWOTNY, Helga; TASCHWER, Klaus. Wissenschaftsforschung. Eine Einführung. Frankfurt/Main, New York: Campus Verlag, 1995.

GLOTZ, Peter. Von der Zeitungs- über die Publizistik-zur Kommunikationswissenschaft. In: Publizistik, v. 35, n. 3, p. 245 - 256, 1990.

HEPP, Andreas. Kommunikations- und Medienwissenschaft in datengetriebenen Zeiten. In: Publizistik, v. 61, n. 3, p. 225 - 246, 2016.

HOHLFELD, Ralf; NEUBERGER, Christoph. Profil, Grenzen und Standards der Kommunikationswissenschaft. Eine Inhaltsanalyse wissenschaftlicher Fachzeitschriften. In: Rundfunk und Fernsehen, v. 46, n. 2-3, p. 313 - 332, 1998.

JARREN, Otfried. Nicht Daten, sondern Institutionen fordern die Publizistikund Kommunikationswissenschaft heraus. Zu Andreas Hepps Beitrag „Kommunikations- und Medienwissenschaft in datengetriebenen Zeiten". In: Publizistik, v. 61, n. 4, p. 373 - 383, 2016.

KOENEN, Erik; SANKO, Christina. Communication Studies as Social Science. Trajectories of the Evolvement and Institutionalization of the Socio-scientific Paradigm in German Communication Studies, 1960s-1980s. In: Revista FAMECOS, v. 23., n. 3, set./dez., 2016. Disponível em: http://revistaseletronicas. pucrs.br/ojs/index.php/revistafamecos/article/view/24478/14613 Acesso em: 31 mar. 2017.

KRÖLL, Friedhelm. Kommunikationswissenschaft. Auswertung einer Umfrage zur Entwicklung und Situation des Faches im deutschsprachigen Raum. In: Publizistik, v. 25, n. 4, p. 492 - 514, 1980.

LÖBLICH, Maria. Die empirisch-sozialwissenschaftliche Wende in der Publizistikund Zeitungswissenschaft. Köln: Herbert von Halem, 2010.

LÖFFELHOLZ, Martin; QUANDT, Thorsten (eds.). Die neue Kommunikationswissenschaft. Theorien, Themen und Berufsfelder im Internet-Zeitalter. Eine Einführung. Wiesbaden: Westdeutscher Verlag, 2003.

NEVERLA, Irene. Warum die deutsche Kommunikationswissenschaft durchaus Zukunft hat. Eine Replik auf Alphons Silbermann. In: Die Zeit, n 5, 1997. Available: http:// www.zeit.de/1997/05/neverla.txt.19970124.xml Accessed in: 31 mar. 2017. 
PEISER, Wolfram; HASTALL, Matthias; DONSBACH, Wolfgang. Zur Lage der Kommunikationswissenschaft und ihrer Fachgesellschaft. Ergebnisse der Mitgliederbefragung der Deutschen Gesellschaft für Publizistik- und Kommunikationswissenschaft 2003. In: Publizistik, v. 48, n. 3, p. 310 - 339, 2003.

RÖSSLER, Patrick; THEIS-BERGLMAIR, Anna Maria. Integration statt Ausgrenzung. In: Aviso, n. 23, p. 7, 1999.

RÜHL, Manfred. Kommunikationswissenschaft zwischen Wunsch und Machbarkeit. Einige Betrachtungen zu ihrer Identität heute. In: Publizistik, v. 30, n. 2-3, p. $229-246,1985$.

Alphons Silbermanns Gespür für den Schnee von gestern. In: Publizistik, v. 42 n. 2, p. $157-163,1997$.

RUSS-MOHL, Stephan. Das Fach ist durchaus leistungsfähig. Aber die Kommunikationsforscher müssen noch kommunizieren lernen. Eine Replik auf Alphons Silbermann. In: Die Zeit, n. 6, 1997. Available: http://www.zeit. de/1997/06/russmohl.txt.19970131.xml. Accessed in: 31 mar. 2017.

SAXER, Ulrich. Grenzen der Publizistikwissenschaft. Wissenschaftswissenschaftliche Reflexionen zur Zeitungs-/Publizistik-/Kommunikationswissenschaft seit 1945. In: Publizistik, v. 25, n. 4, p. 525 - 543, 1980.

SELBSTVERSTÄNDNISAUSSCHUSS DER DEUTSCHEN GESELLSCHAFT FÜR PUBLIZISTIKUND KOMMUNIKATIONSWISSENSCHAFT (self-conception committee). Materialien und Protokolle der Sitzungen, 2006-2008. Available: http://www. phil-fak.uni-duesseldorf.de/en/chair-i-prof-dr-gerhard-vowe/sv-ausschuss/ Acessed: 31 mar 2017.

SILBERMANN, Alphons. Marottenhafte Wichtigtuerei. Ein Abgesang auf die deutsche Medien- und Kommunikationswissenschaft. In: Die Zeit, n. 51, 1996. Available: http://www.zeit.de/1996/51/komm.txt.19961213.xml. Acessed: 31 mar. 2017.

STÖBER, Rudolf. Selbst ist das Verständnis. Selbstverständnisausschuss der DGPuK hat die Arbeit aufgenommen. In: Aviso, n. 43, p. 26 - 27, 2006.

SZYSZKA, Peter. Publizistik und/oder Kommunikationswissenschaft? In: Aviso, n. 21, p. 8, 1998.

THEIS-BERGLMAIR, Anna Maria. Expansion des Fachs oder Expansion auf Kosten des Fachs? Anmerkungen zur zweiten Tagung des Selbstverständnisausschusses. In: Aviso, n. 24, p. 7, 1999.

. To whom it may concern... Aktuelles aus dem Selbstverständnisausschuss. In:

Aviso, n. 26, p. 8, 2000. 
THEIS-BERGLMAIR, Anna Maria; KOHRING, Matthias. Gesellschaftliche Relevanz, Situation und Perspektiven. Kommunikations- und Medienwissenschaft in Deutschland. In: Medien Journal, v. 24, n. 2, p. 28 -35, 2000.

THEIS-BERGLMAIR, Anna Maria. Auf dem Weg zu einer Kommunikationswissenschaft. $\mathrm{Zu}$ Andreas Hepps Beitrag "Kommunikations- und Medienwissenschaft in datengetriebenen Zeiten". In: Publizistik, v. 61, n. 4, p. 385 - 391, 2016.

VOWE, Gerhard. Notwendig, anregend, hilfreich. In: Aviso, n. 45, p. 5 - 6, 2007.

WAGNER, Hans. Kommunikationswissenschaft - ein Fach auf dem Weg zur Sozialwissenschaft. Eine wissenschaftsgeschichtliche Besinnungspause. In: Publizistik, v. 38, n. 4, p. 491 - 526, 1993.

WERSIG, Gernot. Viel Erfolg und wenig Innovation. Die deutsche Kommunikationswissenschaft muss nachdenken. In: Aviso, n. 20, p. 12, 1997.

WISSENSCHAFTSRAT (German Council of Science and Humanities). Empfehlungen zur Weiterentwicklung der Kommunikations- und Medienwissenschaften in Deutschland. Drucksache 7901-07, 2007. Available in: http://www. wissenschaftsrat.de/download/archiv/7901-07.pdf . Accessed: 31 mar. 2017.

WILKE, Jürgen. Von der "entstehenden" zur" etablierten" Wissenschaft. Die institutionelle Entwicklung der Kommunikationswissenschaft als universitäre Disziplin. In: HOLTZ-BACHA, Christina; KUTSCH, Arnulf; Langenbucher, Wolfgang R.; Schönbach, Klaus (eds.). 50 Jahre Publizistik. Wiesbaden: VS, p. 317 - 338, 2005/2006.

WIRTH, Werner. Wachstum bei zunehmender Unübersichtlichkeit. Institutionelle Strukturen und Ausbildungssituation in der Kommunikations- und Medienwissenschaft in Deutschland. In: Medien Journal, v. 24, n. 2, p. 36 - 46, 2000.

ZURSTIEGE, Guido. The Reality of Media Research. In: Nordicom Review, v. 27, n. 2, p. $85-92,2006$.

Recebido em: 6/6/2017

Aceito em: 7/6/2017

Dados dos autores:

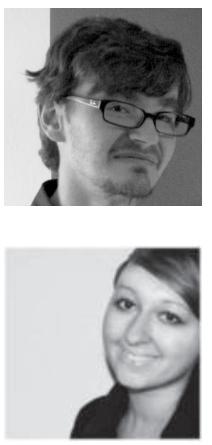

Erik Koenen | ekoenen@uni-bremen.de

Ph.D., research associate (postdoctoral fellow) in the field of communication and media studies, Centre for Media, Communication and Information Research (ZeMKI), University of Bremen, Germany University of Bremen

Bibliothekstraße 1

28359 - Bremen - Germany

Christina Sanko| sanko@uni-bremen.de

M. A., research associate (pre-doctoral fellow) in the field of communication and media studies, Centre for Media, Communication and Information Research (ZeMKI), University of Bremen, Germany University of Bremen

Bibliothekstraße 1

28359 - Bremen - Germany 